\title{
OLIVEIRA, Ricardo Costa de. O silêncio dos Vencedores: genealogia, classe dominante e Estado do Paraná. Curitiba: Moinho do Verbo, 2001. 447 p.
}

José Marciano Monteiro ${ }^{1}$

- Enviado em 14/08/215

- Aprovado em 08/10/2015

Umberto Eco (1995), em sua obra "The Limits of Interpretation",2, afirma que um texto pode ser visto a partir de alguns prismas, dentre estes se destacam: 1) como uma pizza, plano, com recheio por cima, seu significado estando na superfície; 2) como uma torta, tendo várias camadas, com vários recheios, com vários níveis de sentido e significados. O livro "O silêncio dos Vencedores: genealogia, classe dominante e Estado do Paraná”, publicado em 2001, pela Moinho do Verbo, de autoria do Cientista Social e professor da Universidade Federal do Paraná, Ricardo Costa de Oliveira, pode ser compreendido a partir do prisma metafórico de uma torta, conforme proposto por Umberto Eco.

Os significados e os sentidos que a obra apresenta são múltiplos. O texto pode ser compreendido através do prisma das várias camadas: das famílias históricas, que dominaram e dominam politicamente o estado do Paraná; da genealogia como metodologia capaz de explicar processos históricos de concentração de poder e de riqueza; da constituição da classe dominante como resultado das estratégicas de parentesco e acúmulo de capital econômico e político; da família e o parentesco como recurso social fundante do fazer político em um Estado da região Sul do País. Estas são apenas algumas das camadas que formam o texto.

A escrita de Ricardo Costa de Oliveira (2001) está estruturada em cinco partes: 1) Apresentação e formação da classe dominante; 2) Ação e representação da classe dominante; 3) Instituição da classe dominante; 4) Modificação e continuação da classe dominante; e 5)

\footnotetext{
${ }^{1}$ Professor de Sociologia Política e Doutorando em Ciências Sociais pela Universidade Federal de Campina Grande UFCG. E-mail: jm.monteiro17@gmail.com
}

${ }^{2}$ ECO, Umberto. The limits of Interpretation. Indiana Univ. Pres, 1995. 
Identificação da classe dominante. O autor compreende o Paraná como um Estado profundamente sintonizado com o centro da gravidade política brasileira. A classe dominante paranaense caracterizada por padrões de continuidade pelas quais a sua história e suas memórias são filtradas. A produção do silêncio como parte constitutiva da identidade política paranaense.

A classe dominante, como conceito central, é pensada através de três dimensões. A primeira diz respeito à formação material. Através da economia política, investiga as principais atividades econômicas do Estado do Paraná. A segunda, foca nos agentes políticos, e destaca a maneira como atuam politica e culturalmente, estabelecendo relação entre a estrutura e a ação política. E a terceira, tendo como foco o aparelho de Estado regional em 1853, investiga as relações entre estado e classe dominante, através das famílias históricas que perpassam por essas dimensões e enfrentam os desafios de cada conjuntura. Os grupos familiares são encarados em suas concretudes e determinações históricas.

Com isso, o autor propõe entender o "O silêncio dos Vencedores". O "silêncio", que ao não dizer, diz muito. O "silêncio" se traduz na linguagem daqueles que detêm as formas históricas de dominação, quer seja através da ocupação dos principais cargos no aparelho do Estado; quer seja na concentração histórica dos meios de produzir a existência humana, através da terra e da industrial a produção da erva-mate, por exemplo. Se por um lado a investigação aborda o silêncio; por outro, o autor, através do materialismo histórico e da genealogia, dar voz a denúncia social e política; revela ao trazer a tona o "silêncio dos vencedores", os processos históricos de dominação da classe dominante, através das estruturas de parentesco e do domínio dos meios de produzir a existência. Denuncia, através da crítica sociológica, processos históricos de dominação instaurados no decorrer do tempo pelas famílias históricas que a silenciam.

As categorias utilizadas para desvendar os processos camuflados pela dominação política e econômica estão no lastro epistemológico do marxismo. Elas ganham vida quando a classe dominante é entendida na materialidade da produção sócio histórica das famílias. Os agentes que formam a classe dominante são materializados na escrita através dos seus nomes e as estruturas de parentesco que vão se imbricando e dando corpo ao conceito muitas vezes abstrato de classe dominante. As famílias históricas, incorporadas ao texto, vão constituindo a classe dominante, através de uma investigação que tem como fio condutor a historiografia e a genealogia das famílias históricas que remontam ao período colonial. Essas famílias históricas do Brasil colônia, de acordo com Oliveira (2001), permanecem formando significativamente quadros políticos no Brasil republicano do século XX e, por que não afirmar, do século XXI. Demonstra empiricamente que 
parte significativa da elite política paranaense do final da República Velha, nada mais seria do que netos e bisnetos da elite política de meados do século XIX.

O núcleo da elite política é formado por poucas famílias, destaca Oliveira (2001). Famílias estas que controlavam a sociedade, a economia e a cultura regional. Esses grupos familiares históricos formam a classe dominante, visto que sua materialidade é composta pela inserção econômica - produção da erva-mate - e política que assumem no comando da sociedade local e regional. Para tal constatação, o autor recupera o conceito de longa duração, de Fernand Brandel, como instrumento capaz de dar sustentação a genealogia e a economia política, enquanto formas de apreensão dos processos de dominação da classe dominante em uma dada determinação histórica. História, genealogia e economia política, tornam-se inseparáveis no processo de investigação. Metodologicamente uma das principais contribuições que Oliveira acrescenta aos estudos da sociologia política contemporânea.

O enfrentamento da leitura do livro, com aproximadamente 450 páginas, permite, ao leitor, além de encarar os prismas já mencionados, entender a constituição e a lógica de funcionamento da estrutura política e econômica de um dos estados pujante da nossa federação - o Paraná. Possibilita entender a forma que a classe dominante, através das estruturas de parentesco, tendo as famílias históricas como unidade social formadora de processos de dominação política e econômica, se perpetua e se reproduz no poder.

Notadamente, embora o lócus da pesquisa de Ricardo Costa de Oliveira (2001) se limite ao território do Estado do Paraná, a sua abordagem compreende o regional como um componente do nacional. De tal forma que aquele passa ser compreendido de forma relacional com este. Uma parte inserida no todo. A investigação abre caminhos e, por analogia, possibilidades de compreensão acerca da constituição da classe dominante em qualquer estado da federação.

Trata-se de um livro imprescindível, de uma leitura obrigatória, àqueles que pretendem compreender a constituição e formação da classe dominante ou das elites políticas através das famílias históricas em nosso país; uma contribuição à sociologia política e a ciência política contemporânea. Um convite à degustação, muitas vezes, amarga, pois desvenda não só os processos de dominação por parte da classe dominante, mas através do conceito de longa duração, apresenta como os grupos dirigentes constituem uma das dimensões que possibilitam concentração de poder, renda e, consequentemente, distribuição de desigualdades. 